\title{
Quality of working life: conceptions in Brazilian federal universities
}

\section{Qualidade de vida no trabalho: concepções das universidades federais brasileiras}

\author{
Livia de Oliveira BORGES1 (iD) 0000-0003-2251-1373 \\ Sabrina Cavalcanti BARROS ${ }^{2}$ iD 0000-0002-5953-3456 \\ Nina Schumacher MAGALHÃES ${ }^{3}$ (D) 0000-0002-8138-6405
}

\begin{abstract}
Continuous changes in Brazilian federal universities have affected the lives of workers in these institutions. Considering that reflections on the quality of working life of their civil servants can contribute to rethinking work $r$ and/or people management policies, we aim to identify the quality of working life conceptions and practices of federal universities according to the public information documents made available on the Web pages by the federal universities. We understand quality of working life by considering the different levels of analysis (micro, meso and macro) that intersect with it. We identify and analyze the quality of working life conceptions available on the Web pages of 60 institutions. From the content analysis, we found four conceptions. The most frequent ones were the assistentialist (30.0\%) and systemic and preventive $(33.3 \%)$ conceptions. Limitations and suggestions for further studies were indicated.
\end{abstract}

Keywords: Higher education; Mental health; Public administration; Qualitative analysis.

\section{Resumo}

As contínuas mudanças nas universidades federais brasileiras têm afetado a vida dos trabalhadores dessas instituições. Considerando que reflexões sobre a qualidade de vida no trabalho dos servidores podem contribuir para repensar politicas trabalhistas elou de gestão de pessoas, objetivamos identificar as concepções e práticas de qualidade de vida no trabalho das universidades federais segundo os documentos de informações públicas disponibilizados nas páginas

$\because \boldsymbol{M r}$

1 Universidade Federal de Minas Gerais, Faculdade de Filosofia e Ciências Humanas, Programa de Pós-Graduação em Psicologia. Av. Antônio Carlos, 6627, Pampulha, 31270-901, Belo Horizonte, MG, Brasil. Correspondence to: L.O. BORGES. E-mail: $<$ liviadeoliveira@gmail.com>.

${ }^{2}$ Universidade Federal do Rio Grande do Norte, Faculdade de Ciências da Saúde do Trairi, Curso de Psicologia. Santa Cruz, RN, Brasil.

3 Universidade Federal de Minas Gerais, Faculdade de Filosofia e Ciências Humanas, Curso de Psicologia. Belo Horizonte, MG, Brasil.

How to cite this article

Borges, L. O., Barros, S. C., \& Magalhães, N. S. (2020). Quality of working life: conceptions in Brazilian Federal Universities. Estudos de Psicologia (Campinas), 37, e190096. https://doi.org/10.1590/1982-0275202037e190096 
Web pelas próprias universidades federais. Compreendemos qualidade de vida no trabalho atentando para os diferentes niveis de análise (micro, meso e macro) que a atravessam. Identificamos e analisamos as concepções de qualidade de vida no trabalho presentes nas páginas Web de 60 instituições. A partir de análise de conteúdo, encontramos quatro concepções, sendo as mais frequentes a assistencialista $(30,0 \%)$ e a sistêmica e preventiva (33,3\%). Limitações e sugestões de novos estudos foram indicadas.

Palavras-chave: Educação superior; Saúde mental; Administração pública, Análise qualitativa.

Quality of Working Life (QWL) has been approached as a strategic function of people management (Figueira \& Ferreira, 2013). Performing such a function requires the involvement of the organization/institution as a whole and does not develop independently from the social scenario (internal and external). The dynamism of the scenario of federal universities encouraged us to ask, then, about their QWL considerations. Such a scenario can be characterized by the changes experienced by these institutions. Some stem from educational and scientific policies (Souza, Filippo, \& Casado, 2018), such as: the expansion of undergraduate courses (Pizzio \& Klein, 2015); the expansion, systematization and internationalization of postgraduate studies and research activities (Castro \& Cabral-Neto, 2012); valuing the social insertion of university institutions; and the budgetary cut policies of the federal government (Ribeiro \& Leda, 2016). Other changes result from the use of information and communication technologies (Silva, Menezes, \& Bissani, 2002) and the search for a balance between participation in decision-making processes and operational red tape (Matos, Siqueira, Monte, \& Cavalcante, 2015).

Since we are focusing on the QWL theme, in this context, we were also struck by those changes in the world of work, such as: the social security reform, which changed retirement rules differentiating between civil servants before and after the reform (Rodrigues \& Afonso, 2015); the creation of the Empresa Brasileira de Serviços Hospitalares (EBSERH, Brazilian Hospital Services Company), introducing an exclusive legal system for civil servants in federal universities (Garcia-Primo \& Borges, 2018); an increasing rigor in evaluating postgraduate productivity and other university actions, doubts persisting about the exacerbation of competitiveness, individualism and the incompatibility between a short-term view and the production of knowledge (Geraldini \& Bicalho, 2016); the exposure of professors to demands and intellectual production goals without the proportional advances in working conditions (Geraldini \& Bicalho, 2016; Pizzio \& Klein, 2015; Ribeiro \& Leda, 2016; Ruza \& Silva, 2016; Santos, Azevedo, Araújo, \& Soares, 2016); difficulties in maintaining highly qualified staff; an increased number of psychological illnesses and suffering (Ruza \& Silva, 2016), which has alerted to cases of suicide (Forattini \& Lucena, 2015; Leite, 2017; Ramos \& Macêdo, 2018) and/or weakened the professional identity of professors (Lindino, 2016 ).

In summary, if, on the one hand, part of these changes made universities and those identified with their teaching, research and extension functions pulsate; on the other hand, their consequences have generated concerns and discomfort. If promoting QWL should be a strategic function of people management (Figueira \& Ferreira, 2013), we planned this research to identify the QWL conceptions and practices at federal universities, according to the documents and public information made available on the websites by the institutions themselves. It was also established, as a secondary objective, to examine whether the period in which the institutions were founded is related to the concepts and practices they express.

\section{Assumptions}

We assumed that the relationship between the human being and the world, and among people, is not independent from what they think, nor on their shared symbolic and cultural world (Brunner, 1990/1997). For Brunner (1990/1997), what people think and do constitute a functional unit, in which saying what you

2 think or do is also a social action. Then, when we refer to the QWL conceptions and practices adopted by 
a university and publicly documented, we are describing the ways of thinking and acting interdependently and that are historically constructed in the experiences of the institutions in the interactional, normative, conflictive and certain sociomaterial conditions, among other aspects. In other words, they are sets of beliefs.

We should not forget that federal universities adopt participatory management with collegiate bodies of representation. As a consequence, what different administrations register (issue) as standards, thoughts, intentions and practices represent, to a certain extent, the interactions between their members, intersecting with the insertion of institutions and their members in contemporary society. The conceptions and practices to which we referred are, therefore, not scientific approaches, although it can be expected that the latter will have a degree of influence on them, since universities and their servants are implied in the production and dissemination of scientific knowledge. We understood, therefore, that the identification of such conceptions and practices in this research cannot ignore the theoretical contribution on the QWL and, consequently, we proceeded to synthesize the performed review.

\section{Quality of working life}

According to some authors (Ferreira, 2011; Pracidelli \& Rossler, 2018; Sant'Anna, Kilimnik, \& Moraes, 2011), addressing the QWL is a challenge in the sense of differentiating it from its vulgarization, which confuses with organizational marketing, public relations strategies, self-help, assistance and/or compensatory programs (for example, offering work-based physical activities and additional payments for hazardous duty). However, fortunately, we recognized that there are scientific approaches (Hackman \& Oldham, 1975; Mejbel, Almsafir, Diron, \& Alnaser, 2013), including Brazilian researchers (Carvalho, Domingues-Júnior, \& Sant'Anna, 2017; Ferreira, 2015; Sant'Anna et al., 2011; Silva \& Oliveira, 2017). This does not mean that the tendency for organizations to use QWL programs with the intention of reconciling the interests of capital and labor has been overcome; this trend was considered by some authors (Padilha, 2010; Pracidelli \& Rossler, 2018) as illusory and responsible for deepening the alienation of work. On the contrary, the mentioned implications require a critical view of the concepts and/or theoretical models in vogue.

The consolidation and social acceptance of the movement for QWL (González, Peiró, \& Bravo, 1996; Sant'Anna et al., 2011) have been accompanied by the growing attention to movements related to civil rights, corporate social responsibility and movements in favor of citizenship, equal opportunities for jobs, job enrichment and participation in work. But it also came to be understood, according to Sant'Anna et al. (2011), as a way to increase productivity.

González et al. (1996) clarified the existence of several concepts about QWL, according to the highlighted objectives. Thus, the concepts include QWL as an individual reaction to work, institutional actions, a set of improvement methods and strategies, social movement and even the negotiation of different collectives within the same organization. Despite this, Sant'Anna et al. (2011, p.9) considered the understanding of QWL to be consensual, as "a movement of reaction to the rigor of taylorist methods and, consequently, as an instrument that aims to provide greater humanization of work". In such a theoretical and work organization context, Walton (1973) had already considered the relationship between QWL and environmental and human values, neglected by industrial societies in favor of technological advancement, productivity and economic growth.

However, all alternative and humanist initiatives, inserted in the capitalist environment, tend to be incorporated and, in the case of QWL, as a way to increase productivity. Therefore, we follow the evaluation (Ferreira, 2011; Padilha, 2010; Pracidelli \& Rossler, 2018) that QWL, in its common sense and assistentialist perspectives, tends to represent a theatricalization of humanization. These authors prefer, however, the continuity of the implementation of QWL programs to the omission in the theme. We defend the strengthening 
of the movement, as a way to reduce damage and try to break with common sense, assistentialism, the reduction of approaches to focus only on individual reactions, functioning as internal marketing and the superficial appeasement of labor conflicts.

Sant'Anna et al. (2011) presented the classic models of QWL, elucidating their limitations and assumed the Hackman and Oldham model (1975) as the most appropriate one. They concluded that the QWL results from the combination of basic dimensions of the task, generating psychic states that, in turn, result in motivation, satisfaction and high-quality production, in addition to organizational results such as reduced absenteeism and turnover. The environmental aspects would be represented in specific satisfactions (e.g., possibilities for growth, security or compensation). These aspects would relate to the basic dimensions of the task and the results. We consider that individual reactions predominate in the predicted results of the model. The focus would be the adjustment of people to the work environment and their levels of analysis would intersect with the individual, interpersonal relationships and organizational aspects (quality of production, absenteeism and turnover). The model also seems to ignore the intertwining levels of macro-structural and conjunctural analysis.

Sant'Anna et al. (2011) registered, as limitations of the QWL models, their elitist character, whose research tends to focus on top- and medium-level management and large corporations, as well as a predominantly diagnostic perspective. Therefore, they mentioned the contributions of Limongi-França (2009) as more consistent to the notion of management.

Limongi-França (2009) and Tongo (2015) argued that QWL actions should generate economic and human sustainability. Limongi-França $(2009$, p.275) conceptualized QWL as "the set of individualized wellbeing choices that provides positive self-esteem, perception of balance, healthy habits and readiness to the healthy performance of work". Such a concept, however, transformed QWL into an attitudinal issue, of individual responsibility and almost a trait of people. It contradicts its proposal to expand indicators and distanced itself from current trends in seeking to understand social phenomena at different (e.g., micro, meso and macroanalytical), intertwined (Lhuilier, 2014; Grote \& Guest, 2017) levels of analysis. It is assumed, then, as a starting point, the concept of Leite, Ferreira, and Mendes (2009, p.112):

QWL is the result of a set of individual and group actions carried out in organizations, with a view to achieving a context of production of goods and services in which work conditions, organization and social relationships contribute to the prevalence of well-being of the workers.

Leite et al. (2009) also thought of QWL as a phenomenon and/or collective actions. We consider that the concept of these authors rescued what González et al. (1996) had signaled about the need to embrace working conditions, in addition to taking workers as active subjects in the construction of QWL. More recently, Ferreira (2015) listed as structuring factors of well-being (or malaise): working conditions (physical-, material- and installations); work organization; socio-professional relationships (hierarchical and horizontal), recognition and growth; and the link between work and social life.

Limongi-França (2009), despite adopting the aforementioned QWL concept, defended the need for organizations to take responsibility for their internal environment. Leite et al. (2009) also explained the assumptions of the adopted QWL approach, being among these: to have, as a target, the prevention of health problems; to suppose the cooperation between professionals from different backgrounds; to challenge building an organizational space for valuing workers as subjects; to propose an organizational culture aimed at unveiling the creative potential of workers. Ferreira (2015), in turn, ratified the inclusion of health promotion as an indicator in his model of application of work-related ergonomics to the QWL, stating that "the long-lasting experience of the feeling of well-being by workers constitutes a factor of promotion of health in work situations and indicates the presence of QWL" (Ferreira, 2015, p.22). However, Carvalho et al. (2017) 4 and Meneghel and Guimarães (2018) defended quality of life as an antecedent of health and/or stress. In 
any case, the recognition of the relationship between the QWL and human health phenomena is solid, as well as the fact that the cited authors considered the preventive character of QWL programs.

In addition, we remind that the literature linking sometimes mental health, sometimes psychological well-being to working conditions is abundant (Ansoleaga \& Toro, 2014; Camargo, 2017; Costa, Borges, \& Barros, 2015; Dextras-Gauthier, Marchand, \& Haines, 2012; Gasparini, Barreto, \& Assunção, 2005). If health, as a part or as a consequence, is related to QWL, then these relationships between mental health and working conditions corroborate the tendency to include working conditions in research and QWL promotion practices.

Recently, Mejbel et al. (2013), from the Universiti Tenaga Nasional (UNITEN, Tensaga National University), in Malaysia, analyzed scientific articles, finding that QWL drivers are the economic reinforcements, benefits and compensations followed, in decreasing order, by communication strategies (between the management level and other workers), work safety and security and, to a lesser extent, the involvement of senior management, the cohesion provided between work and life in general, job satisfaction and work motivation. Therefore, the authors included working conditions, as well as their own drivers for individual, group and organizational levels. The considerations at the societal level of analysis are implicit in those items related to culture, such as the definition of what are economic reinforcements, benefits and compensations. In the same way, Grote and Guest (2017) defended the inclusion of individual (such as human capacity development) organizational (e.g., a fair compensation and social integration) and societal (e.g., living space and social relevance) indicators.

Some authors (Ferreira, 2015; Grote \& Guest, 2017; Leite et al., 2009; Mejbel et al., 2013) incorporated working conditions in the conception of QWL. However, they would enrich the models if they considered the working conditions in a broad and multidimensional way (e.g., physical and material conditions, contractual and legal conditions, work processes and organization, definition of content, socio-managerial and interpersonal aspects), following how other authors dealt with the theme (Borges et al., 2013; GarcíaLópez, 2017; Ordaz-Castillo \& Maqueda-Blasco, 2014; Ordaz-Castillo \& Ronda-Pérez, 2015; Pietro, Arnal, Caprile, \& Potrony, 2009) and the European Observatory of Working Life. This observatory has focused on the quality of life of people, maintaining a regular survey on working conditions and considering societal institutional crossings, since working conditions reflect the institutional values of labor relations, as well as technological resources and capabilities, among other historical aspects. We observed that all structuring factors of Ferreira (2015) are considered as working conditions in this perspective and that neither Ferreira nor the other QWL-related publications have incorporated the contractual and legal conditions which, in the current transition situation between the third and the fourth industrial revolutions, have been target to precariousness (Alves, 2018; Antunes \& Druck, 2015; Kalleberg \& Hewison, 2013).

We expect that this synthesis about QWL expresses the scope of the theme. This means that systematic QWL programs by institutions, as complex as Federal Universities (FU), should integrate a set of actions and, despite demanding the existence of a specific administrative management unit, be carried out by the organization as a whole, from top managers to the simplest workers. In addition to that, QWL programs will reflect institutional, normative and cultural aspects of the society in which they operate and interact.

\section{Method}

We developed a documentary research on the expression of QWL conceptions on the websites of Brazilian federal universities, according to the following steps: (1) location (during the first semester of 2017) of the list of federal universities (60 institutions) on the website of the Brazilian Ministry of Education; (2) location of the Web pages of each institution; (3) preliminary reading of such pages, searching for direct and indirect mentions to the QWL of their workers, locating and exploring the page of the department of the institution which is specialized in people management, the structure of the department and how the 
information on the management of quality of life is linked to other actions; (4) collection of information and creation of records for each university; (5) reflections on the material collected, thinking about how to develop the analysis; (6) rereading the Web pages, complementing the information already registered; (7) introduction of records in the database of the Qualitative Data Analysis Miner software; (8) categorization, by ourselves, of the QWL conceptions adopted by each FU; (9) production of frequency tables; (10) discussion (by ourselves) of their meanings and readjustment of categorizations; (11) introduction of the variable on the period of functioning of FU (since their foundation); and (12) the elaboration of tables.

The sequence of procedures was inspired by the perspective of content analysis in which subsequent and repeated stages of fluctuating reading, categorization and descriptive statistical treatment are carried out, in addition to searching for the meanings expressed directly or latently in the material under analysis (Bardin, 1977/2011; Minayo, 2000). Such procedures were guided by the presented theoretical framework (psychosociological), making it clear that, in the third and fourth steps, (referring to the data collection and screening on the Web pages), we identified ways of expressing the conceptions of quality of life.

\section{Results}

The analytical procedures performed on these Web pages allowed us to build the classification of the predominant QWL conceptions in each institution (Table 1). Thus, four sets of beliefs (conceptions and practices) were found: (1) Common sense. Institutions that mentioned QWL, on their websites, to designate specific activities (isolated, without articulation with other actions), which serve a small proportion of their workers. We also included, in this conception, an institution that offered alternative therapies, with uncertain results and not widely accepted as scientific-professional techniques. (2) Assistentialist. Institutions with a specialized department highlighted on their websites, inserted in another superior agency (pro-rectory, people management superintendence or human resources administration). However, their proposals focused more on assistance actions (support, assistance and compensation) than prevention and/or anticipation. There are no clearly defined policies. (3) Systemic. Institutions whose QWL-related data are more sophisticated. They are better inserted and articulated with the other actions in the area of people management, showing their awareness that QWL is built within the organization as a whole, although these institutions assign their main responsibilities, or QWL management, to a specific subdivision or sector. (4) Systemic and Preventive. This conception is expressed in institutions where, in addition to meeting the characteristics of the previous conception, there is an intention to develop public health care policies covering the promotion, surveillance and assistance (in the structure of specialized departments and definition of duties). In most of them, the considerations about assistance assignments are prevalent, but the preventive ones covering working conditions are somehow present, at least as a proposition. Table 1 shows that, in addition to these four conceptions, there were no direct or indirect references that would allow us to identify these institutions' QWL conceptions on the websites of 12 institutions (20\% of the total cases).

Table 1

Frequency of conceptions found. Brazil, 2017

\begin{tabular}{lcc}
\hline Concepts & Cases (n) & \% of cases \\
\hline Common Sense Vision & 8 & 13.30 \\
Assistentialist Conception & 18 & 30.00 \\
Systemic Conception & 2 & 3.30 \\
Systemic and Preventive Conception & 20 & 33.30 \\
Omitted (When it was impossible to understand any conceptions) & 12 & 20.00 \\
\hline Total & 60 & 100.00 \\
\hline
\end{tabular}


The second and fourth conceptions are the most frequent ones. However, regarding the fourth concept, despite the consistency of the organizational structures and the articulation between them, in only half of them (10 institutions) references or descriptions of concrete health prevention actions could be found, such as the institutional diagnosis of the well-being of patients, monitoring of working conditions with regular visits to departments, etc. The prevailing surveillance actions are actually based on the records of health complaints from civil servants who are looking for medical assistance, with the need for more institutional proactivity in promoting quality of life. Paying more direct attention to working conditions could facilitate the construction of such proactivity. In addition, only two institutions mentioned the participation of civil servants in the planning of their programs.

In contrast, we observed a predominance of caring with the socialization of information to the civil servant in the institutions. Such caring covered instructions on working rights, career plan, qualification plan and the use of portals of the institutions and/or centralized in the federal government. Part of such portals are important for guaranteeing the rights of civil servants and others for reducing bureaucracy. Both types may impact the quality of life of their civil servants, as the length of bureaucracy remains one of the dilemmas of federal universities (Matos et al., 2015; Silva et al., 2002). However, its real impact requires further studies by listening to servants themselves, seeing that the characteristics of such portals can vary in their acceptance.

Guided by the secondary objective, we questioned whether the expression of such conceptions on the Web pages reflected the tradition and the historical consolidation of universities. Five different university foundation periods were considered (Table 2). Cases of omission were dominant in the universities founded since 2003, suggesting that these are universities that have not yet had enough time to structure QWL actions. However, such omissions did not occur in universities that started to operate between 1985 and 2002, during the redemocratization of the country. Literature (González et al., 1996; Sant'Anna et al., 2011) associated the QWL movement and the redemocratization process, as well as Carvalho et al. (2017) and Pracidelli and Rossler (2018), who dated the 1990s as the popularization period of QWL in Brazil.

Table 2

The QWL conceptions per university foundation period. Brazil, 2017

\begin{tabular}{|c|c|c|c|c|c|}
\hline \multirow{2}{*}{ Concepts } & Common sense & Assistentialist & Systemic & Systemic and preventive & Omitted \\
\hline & \multicolumn{5}{|c|}{$\%$} \\
\hline Until 1963 & 15.40 & 23.10 & 3.80 & 42.30 & 15.40 \\
\hline From 1964 to 1984 & 13.30 & 33.30 & 6.70 & 33.30 & 13.30 \\
\hline From 1985 to 2002 & 25.00 & 25.00 & 0.00 & 50.00 & 0.00 \\
\hline From 2003 to 2011 & 8.30 & 50.00 & 0.00 & 0.00 & 41.70 \\
\hline From 2012 to 2017 & 0.00 & 0.00 & 0.00 & 66.70 & 33.30 \\
\hline
\end{tabular}

The Systemic and Preventive conception is more expressed on the Web pages of the institutions put into operation until 2002 than the other concepts, but the same occurs in institutions that were founded after 2012, suggesting that they have already started to operate while being aware of problems such as attracting professionals and ensuring the continuity of their permanence and productivity. The location of some FU makes it difficult to attract qualified personnel. Such concept is totally absent in FU founded between 2003 and 2011. The tendency of frequency is inverted, in the assistentialist conception, corroborate the deduction that in the newly founded ones, there is a rejection of such a conception.

\section{Discussion}

On the one hand, the results are encouraging in relation to the literature review, given that a tendency to move towards the adoption of preventive systemic concepts can be identified, if the socio- 
cultural conjuncture and/or the institutional societal frameworks is maintained. On the other hand, they corroborate the literature showing that such a tendency is fragile and that there are numerous assistentialist and common-sense conceptions or total omission on the theme. The small number of universities that have updated their QWL conceptions in the direction of incorporating preventive, collective actions that include caring for working conditions does not follow the direction of scientific literature. However, the diversity of conceptions expressed by universities reflects, to some extent, the divergences and evolution of the literature summarized in the introduction of this article. It is up to us, then, to recall the considerations by Ferreira (2011), according to whom, an insufficient and assistentialist view of QWL can produce unwanted consequences for the organization, such as: "... a) the workers' mistrust on the real purposes of the Quality of Working Life Programs (QWLP); (b) the decline, over time, of the adhesion and participation of members of the organization in the Programs; and (c) the commitment to institutional objectives and goals - whose emphasis is on the excellence of performance and productivity - to be achieved with the QWL activities carried out" (Ferreira, 2011, p.9).

The gap between the QWL conceptions found on the FU Web pages and the theoretical approaches and concepts synthesized in the introduction to this article contrasts with the fact that almost all researchers are professors and Stricto Sensu postgraduate students from the same institutions. Then, the following question becomes relevant: why does this happen? Aren't researchers concerned with the application of their studies? Do FU not value the models and reflections of their researchers? Are FUs victims of their servants' work overload? What is the cultural significance of this gap for the role of FUs in disseminating the produced scientific knowledge? We would like to highlight that, for Srour (1998), institutions are productive units and simultaneously political and ideological agents.

In view of these questions, we comment that studies carried out within the scope of public higher education institutions (mentioned in the introduction) indicated that the work of professors encloses vectors that increase QWL, such as: maintaining spaces for creativity and reflection as inherent to all their functions (Maia \& Vieira, 2016); envisioning a work scenario with a social sense for professors, with possibilities for recognition and prestige, as well as challenging projects in which responsibility and autonomy are valued (Ruza \& Silva, 2016); having a recently revised career plan with a high perception of success, being stronger among those in managerial positions and among professors with a doctorate degree (Moreira, Silva, \& Gomes, 2018); having the rewarding character of the teaching-learning relationship and the professor-student interaction; providing continuous opportunities for updating knowledge and technical domains; foreseeing instances of participation by representation among democratic management practices (Ruza \& Silva, 2016).

In contrast, some aspects that negatively compromise the quality of teaching life are already known, such as: work overload and tendency to incorporate routine and bureaucratic tasks (Ruza \& Silva, 2016); lack of synchrony between work demands and intellectual production goals in relation to working conditions, especially in the context of acting in the stricto sensu graduate programs, as well as for obtaining resources and support for research and extension (Geraldini \& Bicalho, 2016; Ruza \& Silva, 2016); tendency to prioritize individualism and the short-term view, contrasting with the demands of knowledge production (Geraldini \& Bicalho, 2016; Lindino, 2016); loss of retirement benefits for a part of the university staff; and the coexistence of different work regimes, implying an experience of inequality (Garcia-Primo \& Borges, 2018). It is beyond the scope of this article to try to discuss all the incremental and difficult vectors, but we would like to point out that there is knowledge produced that, if incorporated by the FU in an articulated way to the QWL actions they adopt, can help them to advance QWL conceptions and practices. The results found in this research, in view of the context, corroborated the tendency observed in the literature review to focus on working conditions, which would benefit QWL practices and allow universities to better hear and understand the complaints of their staff. The focus on working conditions and health prevention would contribute to an 8 application of QWL practices with a collective involvement. 
The examination of the Web pages of the universities did not corroborate our understanding that the available online information about the QWL of FU fulfill only a role of an internal marketing strategy (Sant'Anna et al., 2011), although it is not actually impossible. On the Web pages, those ideals that universities want or intend to practice are expressed, which makes the following question relevant to be asked: why would universities disclose what they do not practice? However, they do mention the Brazilian legislation and the Subsistema Integrado de Atenção à Saúde do Servidor (Integrated Healthcare Subsystem for Civil Servants) suggests that the gap between what is expressed on the Web pages and reality is more likely because of the intention of seeming to comply with legal and governmental requirements regarding inspections and accountability. Anyway, there would be a gap between scientific knowledge about the QWL and institutional actions, corroborating considerations in the literature (Ferreira, 2011; Ferreira, Alves, \& Tostes, 2009; Padilha, 2010; Pracidelli \& Rossler, 2018; Sant'Anna et al., 2011). Knowing whether they consist of a mere publicity stunt without corresponding actions requires new studies addressing institutional actors (civil servants and managers), or through direct observation.

The incipience of preventive care considerations on the Web pages, in the face of the literature (Ferreira, 2015, Leite et al., 2009; Meneghel \& Guimarães, 2018) that strengthens the importance of such measures and factors, like sharing responsibilities and a bigger participation, autonomy, feedback, etc., underline that FUs need to improve their QWL programs. The variations in the frequency of the conceptions and practices identified according to the age of the institutions, in turn, reveal their historical character and that government policies, unique for each administration, go through their symbolic construction.

\section{Contributors}

L. O. BORGES contributed in a coordination and design of research as well analyzing the data and review and approval of the final version of the article. S. C. BARROS contributed with the data analysis and discussion as well writing the text. N. S. MAGALHÃES contributed in data collection, data analysis as well as writing the text in this method.

\section{References}

Alves, G. (2018). A Crise do neodesenvolvimentismo e as perspectivas do trabalho: o Brasil no século XXI. Revista do Tribunal Regional do Trabalho da 15a Região, 53(1), 195-216. Recuperado de https://portal.trt15.jus.br/ documents/124965/2647700/R+53-2018.pdf/53419e44-f9bc-477a-a244-d8487d3c9935

Ansoleaga, E., \& Toro, J. P. (2014). Salud mental y naturaleza del trabajo: cuando las demandas emocionales resultan inevitables. Revista Psicologia: Organizações e Trabalho, 14(2), 180-189. Recuperado el http://submission-pepsic. scielo.br/index.php/rpot/index

Antunes, R., \& Druck, M. G. (2015). A terceirização sem limites: a precarização do trabalho como regra. O Social em Questão, 18(2), 19-40. Recuperado de http://osocialemquestao.ser.puc-rio.br/media/OSQ_34_1_Antunes_Druck.pdf

Bardin, L. (2011). Análise de Conteúdo. São Paulo: Edições 70 (Originalmente publicado em 1977).

Borges, L. O., Costa, M. T. P., Alves-Filho, A., Souza, A. L. R., Rocha-Falcão, J. T., Leite, C. P. R. A., \& Barros, S. C. (2013). Questionário de condições de trabalho: reelaboração e validação de construto. Avaliação Psicológica, 12(2), 213-225. Recuperado de http://pepsic.bvsalud.org/scielo.php?script=sci_arttext\&pid=S1677-04712013000200012

Brunner, J. (1997). Actos de significado: para uma psicologia cultural. Lisboa: Edições 70 (Originalmente publicado em 1990).

Camargo, M. L. (2017). Presenteísmo: denúncia do mal-estar nos contextos organizacionais de trabalho e de riscos à saúde do trabalhador. Revista Laborativa, 6(1), 125-146. Recuperado de http://ojs.unesp.br/index.php/rlaborativa

Carvalho, J. L., Domingues Júnior, P. L., \& Sant'Anna, A. S. (2017). Quality of working life and occupational stress: a Brazilian perspective. International Journal of Business Managemenent and Economic Research, 8(5), 1016-1025. Retrieved from http://www.ijbmer.com/docs/volumes/vol8issue5/ijbmer2017080503.pdf 
Castro, A. A., \& Cabral-Neto, A. (2012). O ensino superior: a mobilidade estudantil como estratégia de internacionalização na América Latina. Revista Lusófona de Educação, 21, 69-96. Recuperado de http://www.scielo.mec.pt/scielo. php?script=sci_arttext\&pid=S1645-72502012000200005

Costa, M. T. P., Borges, L. O., \& Barros, S. C. (2015). Condições de trabalho e saúde psíquica: um estudo em dois hospitais universitários. Revista Psicologia: Organizações e Trabalho, 15(1), 43-58. http://dx.doi.org/10.17652/rpot/2015.1

Dextras-Gauthier, J., Marchand, A., \& Haines, V. (2012). Organizational culture, work organization conditions and mental health: a proposed integration. International Journal of Stress Management, 19(2), 81-104. http://dx.doi.org/10.1037/ a0028164

Ferreira, M. C. (2011). A ergonomia da atividade pode promover a qualidade de vida no trabalho: reflexões de natureza metodológica. Revista Psicologia Organizações e Trabalho, 11(1), 8-20. Recuperado de http://pepsic.bvsalud.org/pdf/ rpot/v11n1/v11n1a02.pdf

Ferreira, M. C. (2015). Ergonomia da atividade aplicada à qualidade de vida no trabalho: lugar, importância e contribuição da Análise Ergonômica do Trabalho (AET). Revista Brasileira de Saúde Ocupacional, 40(131), 18-29. http://dx.doi. org/10.1590/0303-7657000074413

Ferreira, M. C., Alves, L., \& Tostes, N. (2009). Gestão de Qualidade de Vida no Trabalho (QVT) no serviço público federal: o descompasso entre problemas e práticas gerenciais. Psicologia: Teoria e Pesquisa, 25(3), 319-327. http://dx.doi. org/10.1590/\$010237722009000300005

Figueira, T. G., \& Ferreira, M. C. (2013). QVT: "sentir-se bem depois de um dia de trabalho". Revista Laborativa, 2(1), 27-45. Recuperado de https://ojs.unesp.br/index.php/rlaborativa/article/view/856

Forattini, C. D., \& Lucena, C. (2015). Adoecimento e sofrimento docente na perspectiva da precarização do trabalho. Laplage em Revista, 1(2), 32-47. http://dx.doi.org/10.24115/S2446-622020151219p.32-47

García-López, V. (2017). III Encuesta Navarra de Salud y Condiciones de Trabajo. Principales hallazgos. Archivos de Prevención de Riesgos Laborales, 20(2), 102-110. http://dx.doi.org/10.12961/aprl.2017.20.02.3

Garcia-Primo, G. M., \& Borges, L. O. (2018). Trajetória de um hospital universitário: as clínicas associadas à empresa pública. Revista Laborativa, 7(2), 90-111. Recuperado de https://ojs.unesp.br/index.php/rlaborativa/article/view/2517

Gasparini, S. M., Barreto, S. M., \& Assunção, A. A. (2005). O professor, as condições de trabalho e os efeitos sobre sua saúde. Educação e Pesquisa, 31(2), 189-199. http://dx.doi.org/10.1590/S1517-97022005000200003

Geraldini, J. R., \& Bicalho, P. P. G. (2016). Modos de subjetivação no sistema avaliativo da pós-graduação: conhecer, estranhar, interrogar. Revista Subjetividades, 16(1), 49-61. http://dx.doi.org/10.5020/23590777.16.1.78-90

González, P., Peiró J. M., \& Bravo, M. J. (1996). Calidad de vida laboral. In J. M. Peiró, \& F. Prieto (Orgs.), Tratado de Psicología del Trabajo (pp.161-186). Madrid: Síntesis Psicología.

Grote, G., \& Guest, D. (2017). The case for reinvigorating quality of working life research. Human Relation, 70(2), 149167. http://dx.doi.org/10.1177/0018726716654746

Hackman, J. R., \& Oldham, G. R. (1975). Development of the job diagnostic survey. Journal of Applied Psychology, 60(2), 159-170. Retrieved from https://motamem.org/wp-content/uploads/2019/02/Hackman-Oldham-1975-Developmentof-the-JDS.pdf

Kalleberg, A. L., \& Hewison, K. (2013). Precarious work and challenge for Asia. American Behavioral Scientist, 57(30), 271-288. http://dx.doi.org/10.1177/0002764212466238

Leite, J. L. (2017). Publicar ou perecer: a esfinge do produtivismo acadêmico. Revista Katalyusis, 20(2), 207-215. http:// dx.doi.org/10.1590/1982-02592017v20n2p207

Leite, J. V., Ferreira, M. C., \& Mendes, A. M. (2009). Mudando a gestão da qualidade de vida no trabalho. Revista Psicologia: Organizações e Trabalho, 9(2), 109-123. Recuperado de http://pepsic.bvsalud.org/scielo.php?script=sci_ arttext\&pid=S1984-66572009000200010

Lhuilier, D. (2014). Introdução à psicossociologia do trabalho. Cadernos de psicologia Social do Trabalho, 17(1), 5-20. http://dx.doi.org/10.11606/issn.1981-0490.v17ispe1p5-19

Limongi-França, A. C. (2009). Promoção de saúde e qualidade de vida no trabalho: o desafio da gestão integrada. In A. M. Rossi, J. C. Quick \& P. L. Perrewé (Orgs.), Stress e qualidade de vida no trabalho: o positive e o negativo (pp. 256-277). São Paulo: Atlas.

Lindino, T. C. (2016). Quem tu és? Eu? Um professor universitário. Revista Docência do Ensino Superior, 6(2), 35-62. http://dx.doi.org/10.35699/2237-5864.2016.2178 
Maia, M. V. C. M., \& Vieira, C. N. M. (2016). Criatividade docente: winnicott e a construção de subjetividades. Revista Subjetividades, 16(1), 77-90. http://dx.doi.org/10.5020/23590777.16.1.64-77

Matos, N. B., Siqueira, J. S., Monte, P. A., \& Cavalcante, P. R. N. (2015). Práticas de governança eletrônica e desempenho: uma análise nas universidades federais brasileiras. Registro Contábil, 6(2), 130-149. Recuperado de http://www.seer. ufal.br/index.php/registrocontabil/article/view/1638

Mejbel, A. A., Almsafir, M. K., Diron, R., \& Alnaser, A. S. M. (2013). The drivers of quality of working life: a critical review. Australian Journal of Basic and Applied Sciences, 7(10), 398-405. Retrieved from www.researchgate.net/ publication/315728630

Meneghel, V., \& Guimarães, L. A. M. (2018). Qualidade de vida e saúde em trabalhadores pantaneiros da região de Aquidauana, Mato Grosso do Sul, Brasil. In L. A. M. Guimarães \& E. A. N. Cerchiare (Orgs.), Saúde do trabalhador do pantanal de Aquidauna, MS, Brasil: diagnóstico e propostas de intervenção (pp.129-141). Campo Grande: Editora UCDB.

Minayo, M. C. S. (2000). O desafio do conhecimento: pesquisa qualitativa em saúde. São Paulo: Hucitec.

Moreira, M. G., Silva, A. H. S., \& Gomes, M. E. R. (2018). Percepção de sucesso na carreira: um estudo com docentes de universidades federais do Rio Grande do Sul. Pretexto, 19(3), 63-80. http://dx.doi.org/10.21714/pretexto/ v19i34762

Ordaz-Castillo, E., \& Maqueda Blasco, J. (2014). Condiciones de trabajo en el transporte público por carretera. Medicina y Seguridad del Trabajo, 60(234), 90-98. http://dx.doi.org/10.4321/S0465-546X2014000100008

Ordaz-Castillo, E., \& Ronda-Pérez, E. (2015). Salud y condiciones de trabajo en trabajadores mayores. Medicina y Seguridad del Trabajo, 61(240), 314-324. http://dx.doi.org/10.4321/S0465-546X2015000300002

Padilha, V. (2010). Qualidade de vida no trabalho num cenário de precarização: a panaceia delirante. Trabalho, Educação e Saúde, 7(3), 549-63. http://dx.doi.org/10.1590/\$1981-7746200900030000

Pietro, C., Arnal, M., Caprile, M., \& Potrony, J. (2009). La calidad del empleo en España: una aproximación teórica y empírica. Madrid: Ministerio del Trabajo e Inmigración.

Pizzio, A., \& Klein, K. (2015). Qualidade de vida no trabalho e adoecimento no cotidiano de docentes do Ensino Superior. Educação \& Sociedade, 36(131), 493-513. Recuperado de http://www.scielo.br/pdf/es/v36n131/1678-4626-es-3 6-131-00493.pdf

Pracidelli, F., \& Rossler, J. H. (2018). Análise crítica do modelo BPSO-96 de QVT a partir da teoria da atividade de A. N. Leontiev. Ciências Sociais e Humanas, 39(2), 181-196. Recuperado de http://pepsic.bvsalud.org/scielo.php?script=sci_ arttext\&pid=S167654432018000200006\&lng=pt\&nrm=iso

Ramos, L. F. C., \& Macêdo, K. B. (2018). Reflexões sobre o adoecimento dos servidores técnico-administrativos em educação. Argumentum, 10(3), 107-122. http://dx.doi.org/10.18315/argumentum.v10i3.16911

Ribeiro, C. V. S., \& Leda, D. B. (2016). O trabalho docente no enfrentamento do gerencialismo nas universidades federais brasileiras: repercussões na subjetividade. Educação em Revista, 32(4), 97-117. http://dx.doi.org/10.1590/0102-46 98161707

Rodrigues, D. D., \& Afonso, L. E. (2015). O impacto da criação da Funpresp sobre os benefícios previdenciários dos servidores públicos federais. Revista de Administração Pública, 49(6), 1479-1505. http://dx.doi.org/10.1590/0034-76 12141592

Ruza, F. M., \& Silva, E. P. (2016). As transformações na pós-graduação: o prazer no trabalho docente está suspenso? Revista Subjetividades, 16(1), 91-103. http://dx.doi.org/10.5020/23590777.16.1.91-103

Sant'Anna, A. S., Kilimnik, Z. M., \& Moraes, L. F. R. (2011). Antecedentes, origens e evolução do movimento em torno da Qualidade de Vida no Trabalho. In A. S. Sant'Anna \& Z. M. Kilimnik (Orgs.). Qualidade de vida no trabalho: abordagens e fundamentos (pp.3-30). Rio de Janeiro: Campus-Elsevier.

Santos, D. A. S., Azevedo, C. A., Araújo, T. M., \& Soares, J. F. S. (2016). Reflexões sobre a saúde docente no contexto de mercantilização do ensino superior. Revista de Docência do Ensino Superior, 6(1), 159-186. http://dx.doi. org/10.35699/2237-5864.2016.2105

Silva, E. L., Menezes, E. M., \& Bissani, M. (2002). A internet como canal de comunicação científica. Informação \& Sociedade: Estudos, 12(1), 321-343. Recuperado https://www.researchgate.net/publication/311927328A_internet_ comocanalde_comunicacao_cientifica

Silva, U. L., \& Oliveira, A. F. (2017). Qualidade de vida e valores nas organizações: impactos na confiança do empregado. Psicologia: Ciência e Profissão, 37(1), 7-17. http://dx.doi.org/10.1590/1982-3703000012015 
Souza, C. D., Filippo, D., \& Casado, E. S. (2018). Crescimento da atividade científica nas universidades federais brasileiras: análise por áreas temáticas. Avaliação: Revista da Avaliação da Educação Superior, 23(1), 126-156. http://dx.doi. org/10.1590/s1414-40772018000100008

Srour, R. H. (1998). Poder, cultura e ética nas organizações. Rio de Janeiro: Campus.

Tongo, C. I. (2015). Social Responsibility, Quality of Work Life and Motivation to Contribute in the Nigerian Society. Journal of Business Ethics, 126(2), 219- 233. https://doi.org/10.1007/s10551-013-1 940-7

Walton, R. (1973). Quality of working life: what is it? Sloan Management Review, 15(1), 11-21.

Received: August 7, 2019

Final version: February 20, 2020

Approved: April 8, 2020 